\title{
Enhanced Adsorption of Lead (II) Ions from Aqueous Solution by a Chemically Modified Polyurethane
}

\author{
Mangaleshwaran Lakshmipathy, ${ }^{1}$ Muthukumaran Chandrasekaran ${ }^{2}$ \\ and Rasappan Kulanthasamy ${ }^{3}$ \\ ${ }^{1}$ Department of Civil Engineering, Government College of Technology, Coimbatore-641013, Tamilnadu, India \\ ${ }^{2}$ Department of Industrial Biotechnology, Government College of Technology, Coimbatore-641013, Tamilnadu, India \\ ${ }^{3}$ Department of Civil Engineering, Coimbatore Institute of Technology, Coimbatore-641014, Tamilnadu, India \\ *Corresponding author: E-mail: iitmangal@yahoo.com \\ Tel.: +919442051988
}

Received: 10-04-2019

\begin{abstract}
Heavy metal pollution is a major threat to living systems due to increase in the industrial development worldwide. In this study, the adsorption of lead (II) ions by chemically modified polyurethane was reported. Polyurethane (PU) was chemically modified by sulphonation and chlorination to obtain sulphonated PU (SPU) and chlorinated PU (CPU). The adsorption parameters such as $\mathrm{pH}$, contact time, adsorbent loading and initial metal ion concentration were optimized in batch experiments for both the adsorbents. Maximum $\mathrm{Pb}$ (II) ion adsorption of 90 and $85 \%$ was observed for SPU and CPU respectively at optimal conditions. Isotherms results showed that the equilibrium data was fitted with Freundlich isotherm and followed multilayer adsorption mechanism. Adsorption of $\mathrm{Pb}$ (II) ions by both SPU and CPU followed pseudo second order kinetics. The outcome of this study showed that chemical modification of PU is effective for efficient removal of $\mathrm{Pb}(\mathrm{II})$ ions from effluent.
\end{abstract}

Keywords: lead; isotherm; chemical modification; polyurethane, kinetics.

\section{Introduction}

Heavy metal pollution in the environment was mainly caused by the industrial waste discharge to water bodies. ${ }^{1}$ Unlike organic pollutants, heavy metal ions are stable and persistent environmental contaminants which are non biodegradable. Water contaminated by toxic metal ions remains a serious public health problem for human health. ${ }^{2}$ Unique properties of lead like high ductility, flexibility, softness, resistance to corrosion and low melting point have resulted in its widespread usage in different industries like ceramics, plastics, automobiles, paint, etc. This in turn has led to a manifold rise in the occurrence of free lead in biological systems and environment. Human exposure to lead occurs through various sources like battery recycling, coal combustion, leaded gasoline and industrial processes etc. Lead toxicity is particularly insidious hazard with the potential of causing irreversible health effects. It was known to interfere with numerous body functions and it primarily affects he- matopoietic, central nervous, renal and hepatic system producing serious disorders. ${ }^{3}$ Chronic toxicity, on the other hand was much more common and occurs at blood Lead levels of about $40-60 \mu \mathrm{g} / \mathrm{dL}$. It could be much more severe, if not treated in time resulted by encephalopathy, persistent vomiting, delirium, lethargy, convulsions and coma. ${ }^{4,5}$

Several methods commonly employed for $\mathrm{Pb}$ (II) removal from aqueous solution include biosorption, ${ }^{6-7}$ nanofiltration, ${ }^{8}$ ion exchange ${ }^{9}$ and reverse osmosis. ${ }^{10}$ But these methods have the disadvantages like less removal efficiency, require high energy, generation of toxic end products which need further treatments made these processes costly for heavy metal removal at lower concentration. Adsorption is an effective technique with many advantages like convenience, simplicity, efficiency including cost-effectiveness and minimization of secondary wastes. Polyurethane foam (PU) is a cheaper and thermodynamically favorable adsorbent material for heavy metal removal from industrial wastewaters. ${ }^{11}$ Previously, PU was reported as an effective 
adsorbent for removal of nickel, mercury, cadmium etc. ${ }^{12-14}$ The porosity and high surface of PU make it suitable as efficient adsorbent for heavy metal removal. ${ }^{15}$ Mangaleshwaran et al. reported that the efficiency of adsorption can be enhanced by chemical modification of PU. ${ }^{12}$

The aim of the present study was to evaluate the adsorption efficiency of chemically modified polyurethane for $\mathrm{Pb}$ (II) ion removal from aqueous solution. The batch optimization of adsorption parameters ( $\mathrm{pH}$, contact time, adsorbent loading and initial metal ion concentration) was investigated. Adsorption isotherms and kinetics of $\mathrm{Pb}$ (II) ion adsorption were also reported.

\section{Experimental}

\section{1. Synthesis and Chemical Modification of PU}

$25 \mathrm{~mL}$ of toluene diisocyanate (Merck, India) and 25 $\mathrm{mL}$ of tetra methylene ether glycol (Merck, India) was added in acidic condition and form homogenous mixture to initiate polymerization. In the polymerization reaction, initially toluene diisocyanate in acidic medium reacts initially with free available $\mathrm{H}^{+}$ions and then reacts with tetra methylene ether glycol to form PU. After completion of foaming, solid structured open cellular PU was cut into small cubes $(1 \mathrm{~cm})$ and used for further studies. The synthesized PUF was chemically modified by two methods (i) sulphonation and (ii) chlorination. To obtain sulphonated PU (SPU), 25 $\mathrm{mL}$ of $4 \mathrm{~N} \mathrm{H}_{2} \mathrm{SO}_{4}$ (Merck, India) added to $2 \mathrm{~g}$ of PUF and agitated for $45 \mathrm{~min}$ at $60^{\circ} \mathrm{C}$ at $100 \mathrm{rpm}$. After this treatment, the cubes were dried at $105-110^{\circ} \mathrm{C}$ for $3 \mathrm{~h}$. In chlorination reaction, $50 \mathrm{~mL}$ of $0.5 \%$ bleaching powder (Sigma Aldrich, India) solution was added to $2 \mathrm{~g}$ of PUF and agitated for 45 $\min$ at $60{ }^{\circ} \mathrm{C}$ at $100 \mathrm{rpm}$. After this step, the cubes were dried at $105-110^{\circ} \mathrm{C}$ for $3 \mathrm{hrs}$ to get chlorinated PU (CPU) [12]. The chemically modified SPU and CPU were used for further $\mathrm{Pb}$ (II) ion adsorption in batch mode.

\section{2. Preparation of $\mathrm{Pb}$ (II) Adsorbate Solution}

$\mathrm{Pb}$ (II) stock solution was prepared by dissolving 1.6 grams of lead nitrate in a $1000 \mathrm{~mL}$ volumetric flask and diluted using double distilled water to get a $1000(\mathrm{mg} / \mathrm{L})$ concentration. The sample solution concentrations 10-50 $(\mathrm{mg} / \mathrm{L})$ were prepared from stock solution by dilution using double distilled water and the $\mathrm{pH}$ of the samples were adjusted using $0.1 \mathrm{~N} \mathrm{HCl}$ and $0.1 \mathrm{~N} \mathrm{NaOH}$.

\section{3. Batch Adsorption Studies Using SPU and CPU}

The adsorption efficiency of SPU and CPU were studied in a batch mode by varying the adsorption param- eters such as $\mathrm{pH}(2-6)$, contact time (5-150 $\mathrm{min})$, adsorbent dosage $(0.25-3 \mathrm{~g} / 50 \mathrm{~mL})$ and initial adsorbate concentration $(10-50 \mathrm{mg} / \mathrm{L})$. At the end of each batch experiment, remaining $\mathrm{Pb}$ (II) ion concentration was determined by measuring absorbance in UV-Vis spectrophotometer at $520 \mathrm{~nm}$ as per IS 3025 (Part 47): 2003 procedure. The adsorption efficiency was calculated using following Eq.1

$$
\begin{aligned}
& \mathrm{Pb}(\mathrm{II}) \text { adsorption efficiency }= \\
& =\frac{(\text { Initial absorbance-final absorbance })}{\text { Initial absorbance }} \times 100
\end{aligned}
$$

\section{4. Desorption and Reusability Studies}

For desorption studies, $\mathrm{NaOH}$ was chosen as regenerant since the adsorption was carried out in acidic environment. $50 \mathrm{~mL}$ of $0.2,0.4,0.6,0.8$ and $1.0 \mathrm{~N} \mathrm{NaOH}$ was taken in $250 \mathrm{~mL}$ Erlenmeyer flask and $1 \mathrm{~g}$ of adsorbents (SPU, CPU after adsorption) was added separately in each flask, agitated at $100 \mathrm{rpm}, 120$ minutes for $\mathrm{Pb}$ (II) ions desorption. After desorption, the adsorbents were taken out and dried. The dried adsorbents were employed for adsorption of $50 \mathrm{~mL}$ of $\mathrm{Pb}$ (II) solution $(10 \mathrm{mg} / \mathrm{L})$ and their removal efficiency was calculated by measuring the absorbance after adsorption. A plot between maximum removal efficiency and concentration of regenerant was plotted and optimum dose of regenerant was selected. The adsorption and desorption process were repeated for 5 cycles and the $\mathrm{Pb}$ (II) removal efficiency were calculated.

\section{Results and Discussion}

\section{1. Batch Adsorption Studies Using SPU and $\mathrm{CPU}$ on $\mathrm{Pb}$ (II) ion Adorption}

Batch experiments were carried out to study the factors affecting the adsorption process such as $\mathrm{pH}$, contact time, adsorbent dosage and initial adsorbate concentration on $\mathrm{Pb}$ (II) ion adsorption by SPU and CPU.

\section{1. 1 Effect of $\mathrm{pH}$}

In order to study the effect of $\mathrm{pH}$ on $\mathrm{Pb}$ (II) adsorption, experiments were carried out for SPU and CPU at the $\mathrm{pH}$ range (2 to 6) keeping the contact time constant as 150 min. For SPU, the $\mathrm{Pb}$ (II) ion adsorption efficiency was observed increase with increase in $\mathrm{pH}$ from 2 to 4 and above $\mathrm{pH} 4, \mathrm{~Pb}$ (II) ion removal efficiency was declined (Fig.1a). The maximum $\mathrm{Pb}$ (II) ion removal efficiency of $90 \%$ was obtained at $\mathrm{pH} 4$ for SPU. Similar to SPU, the maximum $\mathrm{Pb}$ (II) adsorption efficiency (79\%) was obtained at $\mathrm{pH} 4$ for CPU whereas the adsorption efficiency was observed lesser than SPU (Fig.1a). The optimal $\mathrm{pH}$ for maximum $\mathrm{Pb}$ (II) absorption by both the adsorbent was found to be 4 
and it was correlated with the results published previously. ${ }^{16-17}$ The results revealed that the optimum $\mathrm{pH}$ at which the maximum $\mathrm{Pb}$ (II) ions removed by SPU and $\mathrm{CPU}$ were in the acidic range. At acidic $\mathrm{pH}, \mathrm{H}^{+}$ions compete with $\mathrm{Pb}$ (II) ions at the adsorbent surface which would hinder $\mathrm{Pb}$ (II) ions reaching the bonding sites of adsorbate caused by the repulsive forces. At higher $\mathrm{pH}>6$, the $\mathrm{Pb}$ (II) ions get precipitated due to hydroxide anions forming lead hydroxide precipitate. This hydroxylated form metals can also compete with metal ions at the active sites of the adsorbent thereby decreasing the adsorption. ${ }^{16}$

\section{1. 2 Effect of Contact Time}

The effect of contact time on the $\mathrm{Pb}$ (II) ion removal efficiency using SPU and CPU at optimized $\mathrm{pH} 4$ was represented in Fig.1b. The $\mathrm{Pb}$ (II) ion removal efficiency of SPU was increased from 18 to $90 \%$ as the contact time was increased from 5 to $90 \mathrm{~min}$ and beyond $90 \mathrm{~min}$, the adsorption of $\mathrm{Pb}$ (II) ion attained equilibrium. Khan et al. ${ }^{18}$ obtained $87.6 \%$ of $\mathrm{Pb}$ (II) ion removal using $0.1 \mathrm{~g} / \mathrm{L}$ of multiwalled carbon nanotubes with the contact time of 90 min which was comparable to the present study. For CPU, $\mathrm{Pb}$ (II) ion adsorption efficiency was initially rapid and in- creased till $120 \mathrm{~min}$. Further increase in contact time beyond $120 \mathrm{~min}$ to $180 \mathrm{~min}$ showed that adsorption attained equilibrium. The maximum $\mathrm{Pb}$ (II) ion removal efficiency $(80 \%)$ by CPU was observed at $120 \mathrm{~min}$. Nordiana and $\mathrm{Siti}^{16}$ also reported similar contact time for maximum $\mathrm{Pb}$ (II) ions removal using activated charcoal and peanut shell. The $\mathrm{Pb}$ (II) ion removal efficiency by SPU and CPU increases rapidly during the initial stage which may be due to that adsorbent sites at the surface were empty and the adsorbate concentration gradient was high. Later, the adsorbate uptake rate was decreased mainly due to the unavailability of adsorption sites in the adsorbent surface. ${ }^{19}$

\section{1. 3 Effect of Adsorbent Dosage}

Absorbent dosage is a critical parameter in the adsorption process to identify the optimal amount of adsorbent required for maximum adsorbate removal. The effect of adsorbent dosage $(0.25-3 \mathrm{~g} / 50 \mathrm{~mL})$ on the adsorption of $\mathrm{Pb}$ (II) ion by SPU and CPU were studied at $\mathrm{pH} 4$ and contact time $90 \mathrm{~min}$ and $120 \mathrm{~min}$ respectively. Fig.1c represents the $\mathrm{Pb}$ (II) ion removal efficiency by SPU and CPU at different adsorbent dosage. The optimal adsorbent dosage of SPU and $\mathrm{CPU}$ was found to be $0.75 \mathrm{~g}$ in $50 \mathrm{~mL}$ and $1 \mathrm{~g}$ in $50 \mathrm{~mL}$ and a)

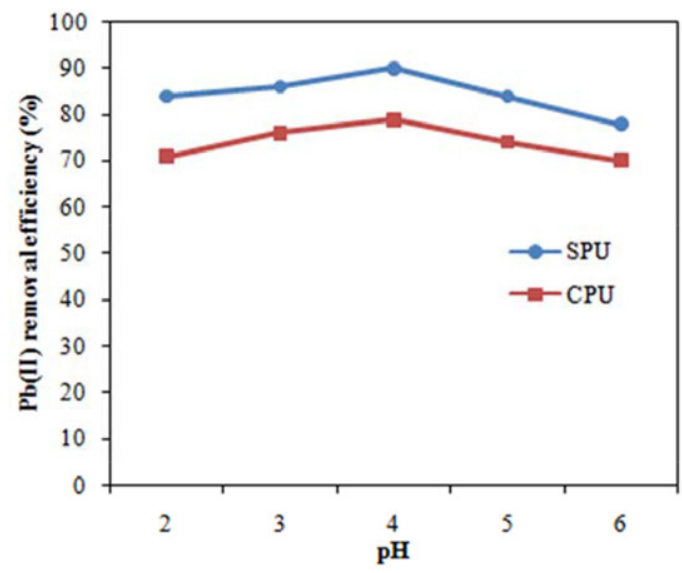

c)

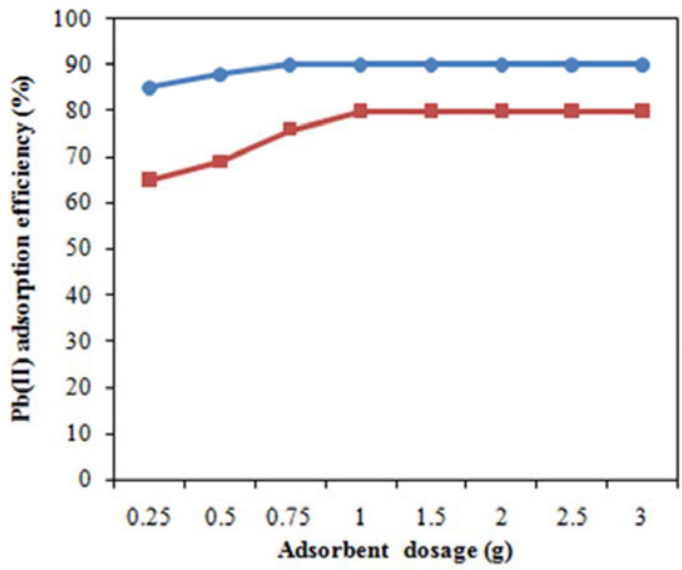

b)

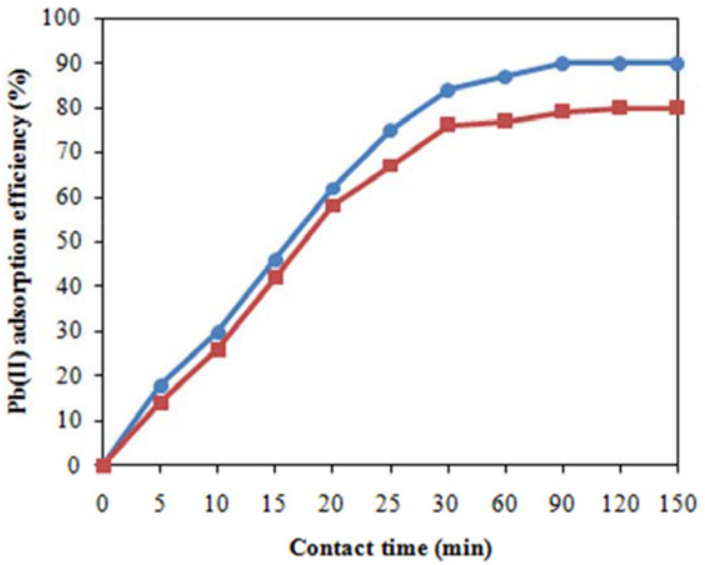

d)

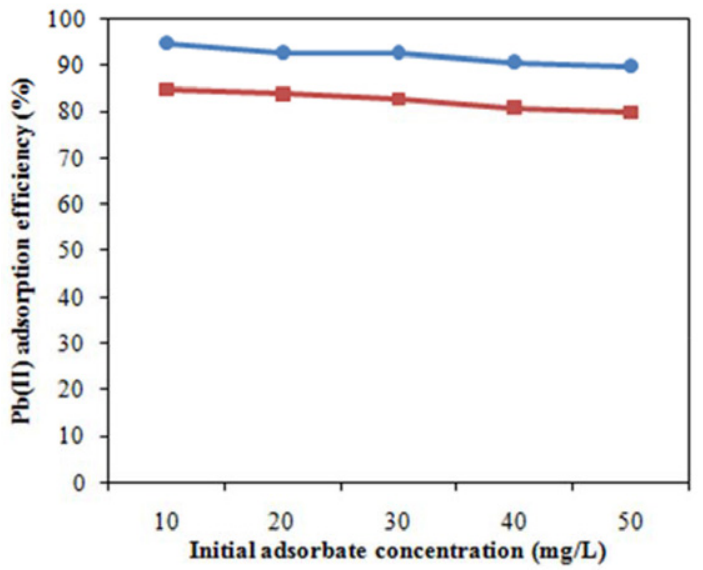

Figure 1. Effect of (a) pH, (b) contact time, (c) adsorbent dosage and (d) initial adsorbate concentration on Pb (II) ion removal efficiency using SPU and $\mathrm{CPU}$ 
the maximum $\mathrm{Pb}$ (II) ion removal of $90 \%$ and $80 \%$ respectively. The increase in removal efficiency with the increase of adsorbent dosage was mainly attributed to the presence of more vacant active sites in the adsorbent surface. ${ }^{20}$

\section{1. 4 Effect of Initial Adsorbate Concentration}

Experiments were carried out to study the effect of initial adsorbate concentration (10-50 mg/L) on $\mathrm{Pb}$ (II) adsorption by SPU and CPU with optimized $\mathrm{pH} 4$, optimized contact time (SPU $90 \mathrm{~min}, \mathrm{CPU} 120 \mathrm{~min}$ ) and optimized adsorbent dosage ( SPU $0.75 \mathrm{~g} / 50 \mathrm{~mL}$, CPU $1 \mathrm{~g} / 50$ $\mathrm{mL}$ ). The trend of $\mathrm{Pb}$ (II) removal efficiency by SPU and $\mathrm{CPU}$ was shown in Fig.1d.At the initial $\mathrm{Pb}$ (II) ion concentration of $10(\mathrm{mg} / \mathrm{L})$, higher $\mathrm{Pb}$ (II) removal efficiency was expected than the other studied concentrations for both SPU and CPU. At lower concentration, the numbers of $\mathrm{Pb}$ (II) ions available in the solution are less as compared to the available sites on the adsorbent. However, at higher concentrations, the available sites for adsorption become fewer, and the percentage removal of lead ions depends on the initial concentration. ${ }^{21}$

\section{2. Adsorption Isotherms}

The mechanism of $\mathrm{Pb}$ (II) ion adsorption onto the adsorbent surface was studied by fitting equilibrium data

a)

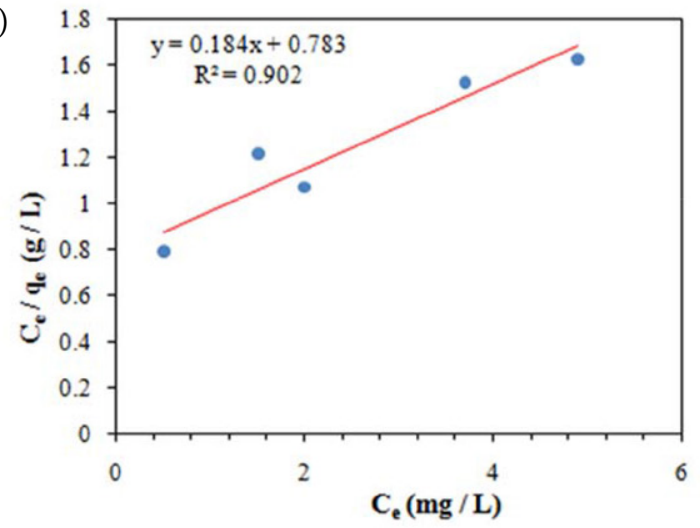

c)

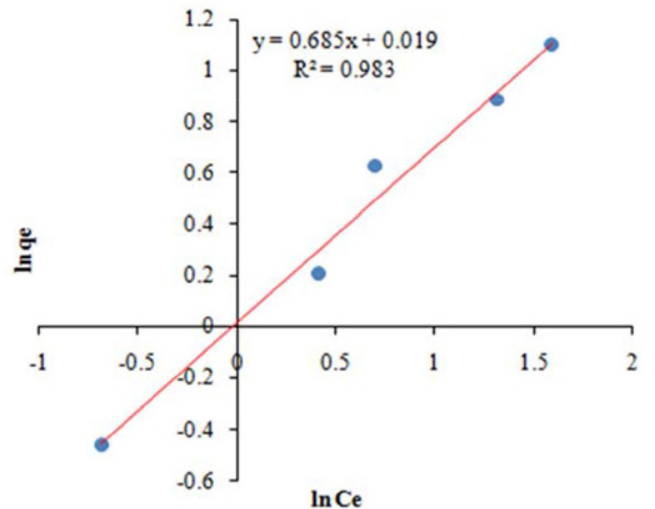

with Langmuir ${ }^{22}$ and Freundlich ${ }^{23}$ isotherm models represented in Eq. 2 and 3.

$$
\begin{aligned}
& \frac{C_{e}}{q_{e}}=\frac{C_{e}}{q_{0}}+\frac{1}{q_{0} b} \\
& \ln q_{e}=\ln K+\frac{1}{n \ln C_{e}}
\end{aligned}
$$

where $q \mathrm{e}(\mathrm{mg} / \mathrm{g})$ is metal adsorbed per mass of adsorbent, $q_{0}$ $(\mathrm{mg} / \mathrm{g})$ is maximum adsorption capacity, $b(\mathrm{~L} / \mathrm{mg})$ adsorption energy constant, Ce $(\mathrm{mg} / \mathrm{L})$ is equilibrium metal ion concentration, $K$ and $n$ were Freundlich isotherm constants.

Langmuir and Freundlich plots for SPU and CPU on $\mathrm{Pb}$ (II) adsorption were represented in Fig. $2 \mathrm{a}-\mathrm{d}$ and the estimated isotherm model constant values were given in Table.1. Based on the $\mathrm{R}^{2}$ value, both the adsorbents fitted well with both the isotherm models and are highly correlated with Freundlich model than Langmuir model (Table.1). The characteristic equilibrium separation factor $R_{L}$ of Langmuir isotherm SPU and CPU were calculated as 0.299 and 0.640 respectively, which indicates the favorable adsorption of $\mathrm{Pb}$ (II) ion on the adsorbent.

The maximum adsorption capacity $\left(\mathrm{q}_{0}\right)$ for SPU and CPU were estimated from Langmuir plot as 5.435 and 5.495 $\mathrm{mg} / \mathrm{g}$ respectively and the obtained results was compared with other adsorbents reported in the previous studies on $\mathrm{Pb}$ (II) ion adsorption (Table.2).The Freundlich isotherm
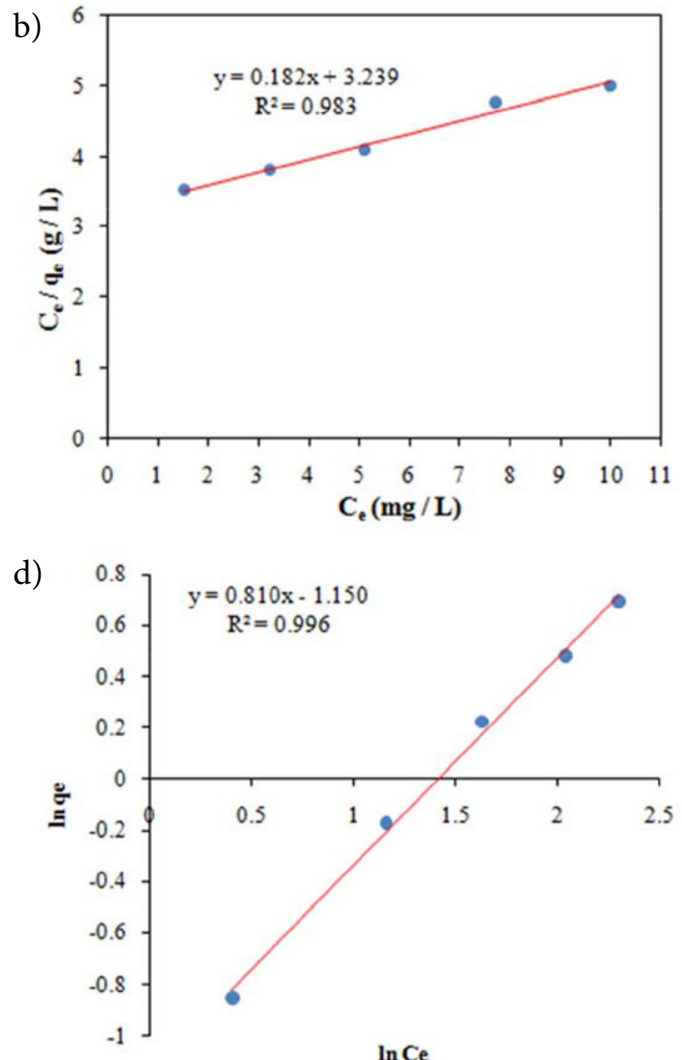

Figure 2. (a \&b) Langmuir isotherms and ( $c \& d$ ) Freundlich isotherm for the adsorbents SPU and CPU. 
Table 1. Estimated constants for Langmuir and Freundlich isotherm models for the adsorption of $\mathrm{Pb}$ (II) ion using SPU and CPU

\begin{tabular}{|c|c|c|c|c|c|c|c|}
\hline \multirow[t]{2}{*}{ Adsorbent } & \multicolumn{3}{|c|}{ Langmuir model } & \multirow[b]{2}{*}{$\mathbf{R}^{2}$} & \multicolumn{3}{|c|}{ Freundlich model } \\
\hline & $\begin{array}{c}\text { b } \\
(\mathrm{L} / \mathrm{mg})\end{array}$ & $\begin{array}{c}\mathrm{q}_{0} \\
(\mathrm{mg} / \mathrm{g})\end{array}$ & $R_{L}=\frac{1}{1+b C_{0}}$ & & $\begin{array}{c}\mathrm{K}_{\mathrm{f}} \\
(\mathrm{mg} / \mathrm{g})\end{array}$ & $\begin{array}{c}\mathbf{n} \\
(\mathrm{L} / \mathbf{m g})\end{array}$ & $\mathbf{R}^{2}$ \\
\hline SPU & 0.235 & 5.435 & 0.299 & 0.902 & 1.019 & 1.460 & 0.983 \\
\hline CPU & 0.056 & 5.495 & 0.640 & 0.983 & 0.316 & 1.235 & 0.996 \\
\hline
\end{tabular}

parameter ' $n$ ' measures adsorption intensity of adsorbent and the value of ' $n$ ' between 1 to 10 indicates favorable multilayer adsorption. Based on the obtained ' $n$ ' values for SPU and $\mathrm{CPU}$, this study revealed that the adsorption of $\mathrm{Pb}(\mathrm{II})$ ion for SPU and CPU favored by multilayer mechanism.

\section{3. Adsorption Kinetics}

The adsorption data were used to fit the pseudo first order $^{24}$ and pseudo second order ${ }^{25}$ kinetic models to predict the controlling mechanism of adsorption.

Table 2. Comparison of Langmuir isotherm model parameters for $\mathrm{Pb}$ (II) ion adsorption using various adsorbents

\begin{tabular}{|c|c|c|c|c|}
\hline \multirow[t]{2}{*}{ Absorbent } & \multicolumn{3}{|c|}{ Langmuir isotherm model parameters } & \multirow[t]{2}{*}{ Reference } \\
\hline & $\mathrm{q}_{\mathrm{o}}(\mathrm{mg} / \mathrm{g})$ & $\mathbf{b}(\mathbf{L} / \mathbf{m g})$ & $\mathbf{R}^{2}$ & \\
\hline Sesame leaf activated carbon & 279.860 & 0.123 & 0.994 & Liu et al. ${ }^{31}$ \\
\hline CS- $\mathrm{Fe}_{2} \mathrm{O}_{3}$ nanocomposite & 214.92 & 0.077 & 0.991 & Ahmad and Mirza, ${ }^{32}$ \\
\hline $\begin{array}{l}\text { 2,2'- Ethylenedithio diethanol immobilized } \\
\text { amberlite XAD } 16\end{array}$ & 107.52 & 11.625 & 0.999 & Khalil et al. ${ }^{33}$ \\
\hline Maize green algae activated carbon & 24.154 & 0.350 & 0.982 & Suresh and Chandrasekaran, ${ }^{21}$ \\
\hline CPU & 5.495 & 0.056 & 0.983 & Present study \\
\hline SPU & 5.435 & 0.235 & 0.902 & Present study \\
\hline Maize leaf activated carbon & 3.713 & 0.627 & 0.998 & Uzma, ${ }^{17}$ \\
\hline Chitosan -G- Polyacrylonitrile & 3.080 & 0.019 & 0.984 & Shanmugapriya et al. ${ }^{34}$ \\
\hline
\end{tabular}

a)

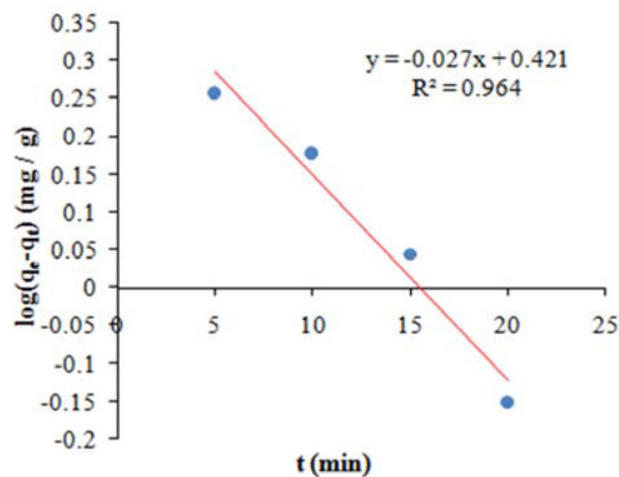

c)

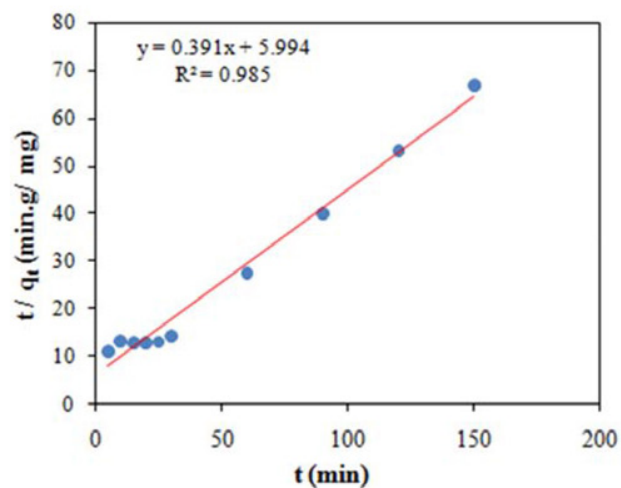

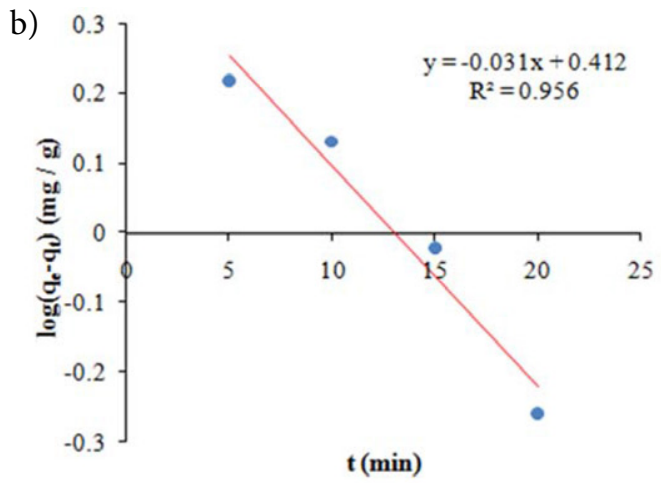

d)

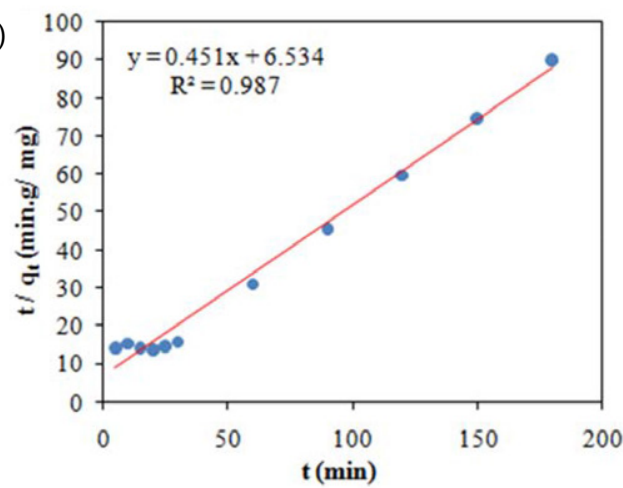

Figure 3. (a \& b) Pseudo first order and (c \& d) Pseudo second order kinetics plot for Pb (II) ion adsorption by SPU and CPU 


$$
\begin{aligned}
& \log \left(q_{e}-q_{t}\right)=\log q_{e}-\frac{k_{1}}{2.303} t \\
& \frac{t}{q_{t}}=\frac{1}{k_{2} q_{e}^{2}}+\frac{t}{q_{e}}
\end{aligned}
$$

where $\mathrm{q}_{\mathrm{e}}$ and $\mathrm{q}_{\mathrm{t}}$ are the amount of metal ion adsorbed $(\mathrm{mg} / \mathrm{g})$ at equilibrium and at time $\mathrm{t}, \mathrm{k}_{1}$ is pseudo first order rate constant $\left(\mathrm{min}^{-1}\right)$ and $\mathrm{k}_{2}$ is pseudo second order rate constant $\left(\mathrm{min}^{-1}\right)$.

The graphs were plotted between $\log \left(q_{e}-q_{t}\right)$ versus $t$ and $t / q_{t}$ versus $t$ to estimate the rate constants for pseudo first order and pseudo second order kinetic model respectively. The kinetic plots for SPU and CPU on $\mathrm{Pb}$ (II) adsorption were shown below (Fig.3a-d). The estimated kinetic constants were given in Table. 3 and observed that the pseudo second order model have good agreement with the experimental data since the $\mathrm{R}^{2}$ values are closer to unity for both SPU and CPU. Similar results were reported for $\mathrm{Pb}$ (II) ions adsorption using different adsorbents. ${ }^{26-27}$ The higher consistency of $\mathrm{q}_{\mathrm{e}}$ experimental with $\mathrm{q}_{\mathrm{e}}$ calculated from pseudo second order model indicates that the adsorption process was controlled by chemisorption. ${ }^{28}$

Table 3. Pseudo first order and pseudo second order kinetic con-

\begin{tabular}{|c|c|c|c|c|c|c|}
\hline \multirow[t]{2}{*}{ Adsorber } & \multicolumn{3}{|c|}{$\begin{array}{l}\text { Pseudo first } \\
\text { order constants }\end{array}$} & \multicolumn{3}{|c|}{$\begin{array}{l}\text { Pseudo Second } \\
\text { order constants }\end{array}$} \\
\hline & $\begin{array}{c}\mathbf{q}_{\mathrm{e}, \mathrm{cal}} \\
\left(\mathrm{mg} \cdot \mathrm{g}^{-1}\right)\end{array}$ & $\begin{array}{c}\mathrm{K}_{1} \\
\left(\mathbf{m i n}^{-1}\right)\end{array}$ & $\mathbf{R}^{2}$ & $\underset{\left(\mathbf{m g} \cdot \mathbf{g}^{-1)}\right.}{\mathbf{q}_{\mathrm{e}, \mathrm{cal}}}$ & $\begin{array}{c}\mathbf{K}_{2} \\
\left(\mathbf{m i n}^{-1}\right)\end{array}$ & $\mathbf{R}^{2}$ \\
\hline SPU & 2.636 & 0.0621 & 0.964 & 2.558 & 0.0255 & 0.985 \\
\hline $\mathrm{CPU}$ & 2.582 & 0.0713 & 0.956 & 2.217 & 0.2060 & 0.987 \\
\hline
\end{tabular}
stant for $\mathrm{Pb}$ (II) ion adsorption by SPU and CPU

\section{4. Desorption and Reusability Studies}

The recycling and regeneration of adsorbent was useful for making the process cost effective by reutilizing the adsorbent for several cycles. ${ }^{29}$ Table. 4 represented the maximum adsorption of $\mathrm{Pb}$ (II) ions using SPU and CPU as adsorbent for five adsorption - desorption cycles. From the adsorption- desorption cycles of $\mathrm{Pb}$ (II) adsorption by SPU and CPU revealed that the adsorption was reversible. However the removal efficiency of each adsorbent (SPU and CPU) was decreasing for each cycles. About 15-22\% of reduction in adsorption efficiency was observed in SPU and 26 to $32 \%$ reduction in adsorption efficiency was observed in CPU after 5 cycles. Similar results were obtained by Lingamdinne et $\mathrm{al}^{30}$ for $\mathrm{Pb}$ (II) ions using graphene oxide based nickel ferrite nano composite for 5 cycles.

\section{Conclusions}

The present study revealed that the efficiency of SPU and $\mathrm{CPU}$ for the removal of $\mathrm{Pb}$ (II) ions from the aqueous
Table 4. Maximum $\mathrm{Pb}$ (II) ion adsorption in adsorption-desorption cycles by SPU and CPU

\begin{tabular}{lccccc}
\hline Adsorbent & \multicolumn{5}{c}{ Adsorption- desorption cycles } \\
& $\mathbf{1}$ & $\mathbf{2}$ & $\mathbf{3}$ & $\mathbf{4}$ & $\mathbf{5}$ \\
\hline SPU & 93 & 89 & 86 & 82 & 78 \\
CPU & 84 & 81 & 78 & 73 & 68 \\
\hline
\end{tabular}

solution was highly depends on $\mathrm{pH}$, contact time, adsorbent dosage and initial adsorbate concentration. $15 \mathrm{~g} / \mathrm{L}$ of SPU effectively removed $95 \%$ of $\mathrm{Pb}$ (II) ion from $10 \mathrm{mg} / \mathrm{L}$ concentrated aqueous solutions at $\mathrm{pH} 4$ for 90 minutes contact time. $20 \mathrm{~g} / \mathrm{L}$ of CPU effectively removed $85 \%$ of $\mathrm{Pb}$ (II) ion from $10 \mathrm{mg} / \mathrm{L}$ concentrated aqueous solutions at pH 4 for 120 min contact time.Adsorption data fitted with Langmuir and Freundlich isotherm model. Based on $\mathrm{R}^{2}$ value, Freundlich isotherm model fitted well than Langmuir adsorption isotherm model. The Langmuir isotherm parameters such as adsorption capacity and adsorption intensity of SPU on $\mathrm{Pb}$ (II) ion adsorption was obtained as $5.435 \mathrm{mg} / \mathrm{g}$ and $0.235 \mathrm{~L} / \mathrm{mg}$ respectively. The adsorption capacity and adsorption intensity of $\mathrm{CPU}$ on $\mathrm{Pb}$ (II) ion adsorption was obtained as $5.495 \mathrm{mg} / \mathrm{g}$ and $0.056 \mathrm{~L} / \mathrm{mg}$ respectively. Kinetic modeling studies revealed that $\mathrm{Pb}$ (II) ion adsorption process onto SPU and CPU followed pseudo second order kinetics. Chemically Modified PU can be utilized as a cheap adsorbent for $\mathrm{Pb}$ (II) ion removal for waste water.

\section{Acknowledgement}

Authors wish to thank The Principal and Head, Department of Civil Engineering, Government College of Technology, Coimbatore for providing facilities to carry out this study.

\section{References}

1. A. Demirbas, A. Sari, O. Isildak, J. Hazard. Mater. 2006, 135, 226-231. DOI:10.1016/j.jhazmat.2005.11.056

2. A. Demirbas, J. Hazard. Mater. 2008, 157, 220-229. DOI:10.1016/j.jhazmat.2008.01.024

3. K. Kalia, S. J. Flora, J. Occup. Health. 2005, 47, 1-21. DOI:10.1539/joh.47.1

4. S. J. S. Flora, G. Flora, G. Saxena, in: S. C. José, S. José (Eds.), Lead: Amsterdam, Elsevier, 2006, pp 158-228.

DOI:10.1016/B978-044452945-9/50004-X

5. J. M. Pearce, European Neurol. 2007, 57, 118-119. DOI:10.1159/000098100

6. Y. Zhu, Y. Jiang, Z. Zhu, H. Deng, H. Ding, Y. Li, L. Zhang, J. Lin, J. Clean. Prod. 2018, 187, 650-661.

DOI:10.1016/j.jclepro.2018.03.275

7. M. Ziati, S. Hazourli, Microchem. J. 2019, 146, 164-169. DOI:10.1016/j.microc.2018.12.041 
8. A. Otero-Fernández, J. A. Otero, A. Maroto-Valiente, J. I. Calvo, L. Palacio, P. Pradanos, A. Hernandez, Clean Technol. Environ. Pol. 2018, 20, 329-343.

DOI:10.1007/s10098-017-1474-2

9. Q. Dong, X. Guo, X. Huang, L. Liu, R. Tallon, B. Taylor, J. Chen, Chem. Eng. J. 2019, 361, 1535-1542.

DOI:10.1016/j.cej.2018.10.208

10. K. Jainaea, K. Sanuwong, J. Nuangjamnong, N. Sukpirom, F. Unob, Chem. Eng. J. 2010, 160, 586-593.

DOI:10.1016/j.cej.2010.03.080

11. C. Yong, G. Yu, G. Zeng, H. Yang, F. Chen, C. Jin, J. Environ. Sci. 2011, 23, 1325-1333. DOI:10.1016/S1001-0742(10)60565-7

12. L. Mangaleshwaran, A. Thirulogachandar, V. Rajasekar, C. Muthukumaran, K. Rasappan, J. Taiwan Inst. Chem. Eng. 2015, 55,112-118. DOI:10.1016/j.jtice.2015.03.034

13. J. F. Flores-Aguilar, C. A. Galán-Vidal, J. A. Rodríguez, J. G. Alvarado-Rodríguez, M. E. Páez-Hernández, Int. J. Environ. Sci. Technol. 2019, 16, 1005-1014.

DOI:10.1007/s13762-018-1723-x

14. M. Sayed, N. Burham, Int. J. Environ. Sci. Technol. 2018, 15, 105-118. DOI:10.1007/s13762-017-1369-0

15. M. Abbas, M. L. Moslem, B. Mehdi, React. Function. Polym. 2014, 83,14-23.

16. S. M. T. Nordiana, Z. A. R. Siti, World J. Sci. Technol. Res. 2013 , 1, 102-109.

17. N. Uzma, European Chem. Bull. 2013, 2, 927-931.

18. T. A. Khan, N. Momina, E. A. Khan, R. Ufana, J. Mol. Liq. 2015, 212, 467-479.

19. A. A. Farghali, M. Bahgat, A. A. Enaiet, M. H. Khedr, Beni-Suef Univ. J. Basic Appl. Sci. 2013, 2, 61-71.

DOI:10.1016/j.bjbas.2013.01.001
20. M. Kumar, J. S. Chung, S. H. Hur, Appl. Sci. 2019, 9, 2925. DOI:10.3390/app9142925

21. J. R. P. Suresh, V. Chandrasekaran, Int. J. Ind. Chem. 2014, 4, $1-10$.

22. I. Langmuir, J. Am. Chem. Soc. 1918, 40, 1361-1403. DOI:10.1021/ja02242a004

23. H. Freundlich, Z. Phys. Chem. 1906, 57, 385-470.

24. S. Lagergren, KSven. Vetenskapsakad. Handl. 1898, 24, 1-39.

25. Y. S. Ho, G. McKay, Process Biochem. 1999, 34, 451-465. DOI:10.1016/S0032-9592(98)00112-5

26. K. Tomasz, K. Anna, C. Ryszard, Microchem. J. 2019, 145, 1011-1025. DOI:10.1016/j.microc.2018.12.005

27. C. Xiong, S.Wang, W. Sun, Y. Li, Microchem. J. 2019, 146, 270-278. DOI:10.1016/j.microc.2019.01.005

28. L. I. Hui, D. L. Xiao, H. E. Hua, L. I. N. Rui, P. L. Zuo, Trans. Nonferrous Metal Soc. China. 2013, 23, 2657-2665. DOI:10.1016/S1003-6326(13)62782-X

29. A. Rashid, N. B. Haq, I. Munawar, N. Saima, Ecol. Eng. 2016, 91, 459-471. DOI:10.1016/j.ecoleng.2016.03.014

30. L. P. Lingamdinne, J. R. Koduru, Y. L. Choi, Y. Y. Chang, J. K. Yang, Hydrometallurgy 2016,165, 64-72.

DOI:10.1016/j.hydromet.2015.11.005

31. L. E. Liu, J. Liu, H. Li, H. Zhang, J. Liu, H. Zhang, BioResources, 2012, 7, 3555-3572.

32. R. Ahmad, A. Mirza, J. Clean. Prod. 2018, 186, 342-352. DOI:10.1016/j.jclepro.2018.03.075

33. T. E. Khalil, A. E. Dissouky, S. Rizk, J. Mol. Liq. 2016, 219, 533-546. DOI:10.1016/j.molliq.2016.03.063

34. A. Shanmugapriya, M. Hemalatha, B. Scholastica, A.P.D. Agustine, Der Pharma Chemica. 2013, 5, 141-155.

\section{Povzetek}

Zaradi vsesplošne industrializacije predstavlja onesnaženje s težkimi kovinami resno grožnjo vsem živim bitjem. V tej študiji smo preučevali adsorpcijo svinčevih (II) ionov na modificiran poliuretan. Poliuretan (PU) smo kemijsko modificirali s sulfonacijo in kloriranjem, s čimer smo pridobili sulfoniran PU (SPU) in kloriran PU (CPU). Pri obeh adsorbentih smo optimirali parametre adsorpcije kot so $\mathrm{pH}$ vrednost, kontaktni čas, količina adsorbenta in začetna koncentracija kovinskih ionov. Pod optimalnimi pogoji smo dosegli $90 \%$ in $85 \%$ adsorpcijo ionov na SPU oziroma CPU. Ravnotežni rezultati adsorpcije so pokazali, da gre za večplastno adsorpcijo, ki jo lahko opišemo s Freundlich-ovo izotermo. Hitrost adsorpcije na oba nosilca je sledila kinetiki pseudo-drugega reda. Rezultati študije so pokazali, da lahko kemijsko modificiran $\mathrm{PU}$ učinkovito odstranjuje $\mathrm{Pb}$ (II) ione iz odplak.

Except when otherwise noted, articles in this journal are published under the terms and conditions of the Creative Commons Attribution 4.0 International License 